\title{
Effect of Plant Regulators on Growth and Flowering of 'MEYER' ZOYSIAGRASS ${ }^{1}$
}

\author{
Efeito de Reguladores Vegetais sobre o Crescimento e o Florescimento de Grama-Esmeralda
}

\author{
MARCHI, S.R. ${ }^{2}$, MARTINS, D. ${ }^{3}$, COSTA, N.V. ${ }^{4}$, and SILVA, J.R.V. ${ }^{5}$
}

\begin{abstract}
This trial aimed to evaluate the effect of sequential applications of different plant regulators over growth and flower rachis emission of 'Meyer' zoysiagrass (Zoysia japonica). The study was conducted on 15-month old green turfgrass under a randomized complete block design with four replications. The following plant regulator and doses were tested: trinexapac-ethyl $(113+113,226+113,226+226,452+113,452+226,452+452,678+339$ e 904+452 g a.i./ ha $\left.\mathrm{g}^{-1}\right)$, prohexadione-calcium (100+100 e 200+200 g a.i. ha $\left.{ }^{-1}\right)$ and bispyribacsodium $\left(40+40\right.$ e 60+60 g a.i. ha $\left.{ }^{-1}\right)$, as well as an untreated control. The turfgrass was mowed again at $3.0 \mathrm{~cm}$ aboveground and the second plant regulator was applied when 'Meyer' zoysiagrass was between 5.0 and $6.0 \mathrm{~cm}$ high. The effect of the treatments was visually rated for visual injury, plant height, height and number of flower rachis, and total dry mass production of clippings. Only bispyribac-sodium had visual symptoms of injury on 'Meyer' zoysiagrass, and no intoxication was observed at 28 days after the second application (DAAB). The sequential applications of trinexapac-ethyl, prohexadione-calcium and bispyribac-sodium reduced by more than $80 \%$ the total clipping dry mass produced by 'Meyer' zoysiagrass. All the plant regulators tested also showed promising results in reducing the height and emission of rachis, especially when trinexapac-ethyl was applied at the doses $452+452,678+339$ and $904+452 \mathrm{~g}$ a.i. ha ${ }^{-1}$. 'Meyer' zoysiagrass turfgrass can be handled with the sequential application of a plant regulator, which reduces the need for mowing over a period up to 110 days after the application of the second plant regulator, and it also avoids deleterious visual effects over turfgrass.
\end{abstract}

Keywords: Zoysia japonica, trinexapac-ethyl, prohexadione-calcium, bispyribac-sodium, sequential application.

RESUMO - Este trabalho teve o propósito de avaliar o efeito da aplicação sequencial de diferentes reguladores vegetais sobre o crescimento e a emissão de hastes florais da grama-esmeralda (Zoysia japonica). O estudo foi instalado em um gramado com 15 meses, no delineamento de blocos casualizados com quatro repetições, e os reguladores de crescimento e doses testados foram: trinexapac-ethyl (113+113, 226+113, 226+226, 452+113, 452+226, 452+452, 678+339e $904+452 \mathrm{~g}$ i.a. ha $\left.\mathrm{h}^{-1}\right)$, prohexadione-calcium $\left(100+100\right.$ e $200+200 \mathrm{~g}$ i.a. ha $\left.\mathrm{h}^{-1}\right)$ e bispyribac-sodium $\left(40+40\right.$ e 60+60 g i.a. ha $\left.\mathrm{h}^{-1}\right)$, além de uma testemunha sem aplicação de regulador de crescimento. Quando os tratamentos atingiram altura entre 5,0 e $6,0 \mathrm{~cm}$, o gramado foi novamente aparado a $3,0 \mathrm{~cm}$ de altura, sendo em seguida realizada a aplicação da segunda dose dos reguladores. $O$ efeito dos tratamentos foi avaliado quanto à fitointoxicação, por meio de avaliação visual, altura de plantas, altura e emissão de hastes florais e produção de massa seca de aparas. Apenas o bispyribacsodium apresentou sintomas visuais de injúria, não se verificando mais intoxicação aos 28 dias após a segunda aplicação (DAAB). As aplicações sequenciais do trinexapac-ethyl, prohexadione-calcium e bispyribac-sodium apresentaram reduções acima de $80 \%$ na quantidade total de massa seca de aparas produzidas pela grama-esmeralda. Todos os reguladores de crescimento também demonstraram

1 Recebido para publicação em 11.7.2012 e aprovado em 26.1.2013.

2 Engo ${ }^{\circ}$. Agr ${ }^{\circ}$., Prof., Dr., Universidade Federal de Mato Grosso - UFMT, Avenida Governador Jaime Campos, 6390 - Barra do Garcas-MT, 78600-000, <sidneimarchi.ufmt@gmail.com>; ${ }^{3}$ Engํ․ Agr ${ }^{\circ}$., Prof., Dr., Faculdade de Ciências Agronômicas FCA/UNESP, Dep. de Produção Vegetal-Agricultura, Fazenda Experimental Lageado, s/n, Caixa Postal 237, 18610-307 Botucatu-SP; ${ }^{4}$ Engo . Agr ${ }^{\circ}$., Prof., Dr., Centro de Ciências Agrárias, Universidade Estadual do Oeste do Paraná, Caixa Postal 91, 85960-000 Marechal Cândido Rondon-PR; ${ }^{5}$ Engo . Agr ${ }^{\circ}$., Dr., Syngenta Proteção de Cultivos Ltda., Avenida das Nações Unidas, 18001 $2^{\circ}$ andar, 04795-900 São Paulo-SP.

Planta Daninha, Viçosa-MG, v. 31, n. 3, p. 695-703, 2013 
ser promissores em relação ao retardamento do crescimento e da emissão das inflorescências, com especial destaque para o trinexapac-ethyl aplicado nas doses de 452+452, 678+339e $904+452 \mathrm{~g}$ i.a. ha $\mathrm{h}^{-1}$. Gramados formados com grama-esmeralda podem sermanejados com a aplicação sequencial de regulador vegetal, com a redução da necessidade de cortes por um periodo de até 110 dias após a aplicação, além de não causar efeito deletério no aspecto visual sobre o gramado.

Palavras-chave: Zoysia japonica, trinexapac-ethyl, prohexadione-calcium, bispyribac-sodium, aplicação sequencial.

\section{INTRODUCTION}

Good turfgrass maintenance provides a safe and comfortable place for leisure and sports activities, reduces air heating, releases oxygen and captures atmospheric $\mathrm{CO}_{2}$, thus mitigating the greenhouse effect, and it also reduces the exposure of the soil to erosion. Turfgrass can be used for different purposes in different locations, such as residential areas, industrial and urban areas, slopes and hillsides and road beds. However, it is best used in sports activities, especially in soccer, golf and baseball fields.

There are dozens of species and varieties of grass for various purposes (Arruda \& Henriques, 1995). The most used in Brazil are: Bahia Grass (Paspalum notatum), American carpet grass (Axonopus compressus) St. Augustine grass (Stenotaphrum secundatum), Korean Velvet grass (Zoysia tenuifolia), Bermudagrass (Cynodon dactylon) and, particularly, 'Meyer' zoysiagrass (Zoysia japonica).'Meyer' zoysiagrass, originally from Japan, is also known as wild zoysia, zoysia grass or simply zoysia. It is a herbaceous rhizomatous creeping perennial grass. It ranges in height from 10 to $15 \mathrm{~cm}$, and it has narrow and small leaves arranged in short and thick stems. It looks like a perfect lawn when mown frequently (Lorenzi \& Souza, 2001).

One of the advantages of using 'Meyer' zoysiagrass is the formation of a beautiful lawn at intermingling of penetrating stolon which roots easily. It has great beauty, tender leaves and resistance to trampling; it is the most versatile type of grass (Alvarez \& Henriques, 1995). However, regardless of the type of use or the choice of species, the major expenditure in the cost of turfgrass maintenance is the use of mowing to maintain proper height (Freitas et al., 2002). The successive mowing operations on the turfs are basically related to plant growth and grass flowering, especially between October and March (Kissmann \& Groth, 1992).

Turfgrass leaves are expected to grow up to a certain limit, beyond which the lower leaves are subject to self-shading and become chlorotic, acquiring yellowish spots after mowing. Another factor that changes the visual quality of turfgrass is the intense flower stem emission, which usually has shades of colors that differ from the color of leaves. Moreover, both the leaves as the flower stems can reach excessive heights, which affect the practice of sports and the comfort of users.

Thus, expenditures on successive mowing operations as well as aesthetic appeal call for alternatives to mechanical management, and one of them is to use plant growth regulators. The use of growth regulators is a common practice in the management of several species of grass in the United States, especially Type I regulators, i.e., inhibitors of cell division, such as mefluidide and maleic hydrazide, and Type II regulators, which are inhibitors of cell elongation, such as trinexapac-ethyl, paclobutrazol and prohexadione-calcium (McCullough et al. 2004; Ervin \& Zhang, 2007). Particularly, Type II regulators are compounds able to modify the concentration of hormones in plants and to promote smooth expansions of leaf area and the development of side structures without incurring undesirable increases in the top growth of grass species (McCullough et al. 2004).

However, growth regulators can produce some undesirable effects if not used carefully. The occurrence of visual injury, thereby changing the visual quality of the turf, is often reported. Leaf injury varies according to environmental conditions: in temperate regions, dark green spots are observed (Ervin \& Koski, 2001; Heckman et al., 2005, McCullough et al., 2006), while discoloration 
characterized by yellowing leaves is seen in tropical regions (Heckman et al., 2001, McCullough et al., 2005, McCarty et al., 2011).

Besides reducing plant growth, Type I growth regulators are also effective in suppressing floral emissions. In contrast, Type II inhibitors are ineffective in suppressing the emission of flower stems (Johnson, 1990; Fry, 1991; Mittlesteadt et al. 2009).

Low-dose single applications usually result in low levels of injury associated with short periods of growth control in height and reduction of inflorescence. In contrast, high doses provide better results for longer periods, but with higher levels of injury. This imbalance between efficiency and injury can be solved with sequential applications involving welladjusted doses (Fagerness \& Yelverton, 2000; Lickfeldt, et al., 2001, McCarty et al., 2004; Waltz Jr. \& Whitwell, 2005; Ervin \& Zhang, 2007; McCullough et al., 2007).

Thus, this study aimed to verify the effect of the sequential application of different doses of growth regulators trinexapac-ethyl, prohexadione-calcium and bispyribac-sodium on growth and flowering of 'Meyer' zoysiagrass.

\section{MATERIAL AND METHODS}

The study was conducted in the experimental area of the Center for Advanced Research in Weed Science - NuPAM, Department of Plant Production, owned by the Faculty of Agricultural Sciences of Botucatu/ UNESP, whose geographic coordinates are: $22^{\circ} 07^{\prime} 56^{\prime \prime}$ S latitude and $74^{\circ} 66^{\prime} 84^{\prime \prime} \mathrm{W}$ longitude, and altitude of 760 meters. The turf, approximately 15 months old, was formed from 'Meyer' zoysiagrass in area which received overhead irrigation. The soil was classified as a red Alfisol, clayish texture, moderate degree, dystrophic (Embrapa, 2006). After application of $2.6 \mathrm{t} \mathrm{ha}^{-1}$ lime, a chemical analysis revealed the characteristics shown in Table 1.
During development, the turf was kept at an average height of $3.0 \mathrm{~cm}$ aboveground by successive mowing with an engine-powered mechanical mower, equipped with a rotary cutting blade and a special device to collect clippings.

The treatments, shown in Table 2, were arranged in a randomized complete block design with four replications. The total area of each plot was $1.5 \mathrm{~m}$ wide and $2.5 \mathrm{~m}$ long, totaling $3.75 \mathrm{~m}^{2}$. Besides the control plot, a strip of $0.5 \mathrm{~m}^{2}$ was maintained along the experimental blocks as lateral control, so that the injury caused by growth regulators could be better monitored.

Applications were made with a $\mathrm{CO}_{2}$ pressurized backpack sprayer containing a bar with two flat spray tips VS TP 80.02, interspaced at $50 \mathrm{~cm}$. The entire assembly was maintained at a constant pressure of 2.0 bar, so that the solution volume was equivalent to $200 \mathrm{~L} \mathrm{ha}^{-1}$.

Table 2 - Growth regulators and doses used in the first and second applications on 'Meyer' zoysiagrass

\begin{tabular}{|l|c|c|c|}
\hline \multirow{2}{*}{\multicolumn{1}{|c|}{ Treatment }} & \multicolumn{3}{|c|}{ Dose $\left(\mathrm{g}\right.$ i.a.ha $\left.^{-1}\right)$} \\
\cline { 2 - 4 } & $\begin{array}{c}1^{\text {st }} \\
\text { Application }\end{array}$ & $\begin{array}{c}2^{\text {nd }} \\
\text { Application }\end{array}$ & Total \\
\hline 1. trinexapac-ethyl & 113 & 113 & 226 \\
\hline 2. trinexapac-ethyl & 226 & 113 & 339 \\
\hline 3. trinexapac-ethyl & 226 & 226 & 452 \\
\hline 4. trinexapac-ethyl & 452 & 113 & 565 \\
\hline 5. trinexapac-ethyl & 452 & 226 & 678 \\
\hline 6. trinexapac-ethyl & 452 & 452 & 904 \\
\hline 7. trinexapac-ethyl & 678 & 339 & 1017 \\
\hline 8. trinexapac-ethyl & 904 & 452 & 1356 \\
\hline 9. prohexadione-calcium & 100 & 100 & 200 \\
\hline 10. prohexadione-calcium & 200 & 200 & 400 \\
\hline 11. bispyribac-sodium & 40 & 40 & 80 \\
\hline 12. bispyribac-sodium & 60 & 60 & 120 \\
\hline 13. Control & - & - & - \\
\hline
\end{tabular}

${ }^{1 /}$ Second application when the average height of the treated area was between 5 and $6 \mathrm{~cm}$ in height.

Table 1 - Attributes for chemical characterization of the soil in the experimental area in the layer of 0-200 $\mathrm{mm}$

\begin{tabular}{|c|c|c|c|c|c|c|c|c|c|c|c|}
\hline $\mathrm{pH} \mathrm{CaCl}_{2}$ & $\mathrm{C}$ org. & $\mathrm{P}$ & $\mathrm{Ca}$ & $\mathrm{Mg}$ & $\mathrm{K}$ & $\mathrm{Al}$ & $\mathrm{H}+\mathrm{Al}$ & $\mathrm{CTC}$ & $\mathrm{V}$ & $\mathrm{Fe}_{2} \mathrm{O}_{3}$ \\
\hline$\left(0,01 \mathrm{~mol} \mathrm{~L}^{-1}\right)$ & $\left(\mathrm{g} \mathrm{kg}^{-1}\right)$ & $\left(\mathrm{mg} \mathrm{kg}^{-1}\right)$ & \multicolumn{6}{|c|}{$\left(\mathrm{mmol}_{\mathrm{c}} \mathrm{kg}^{-1}\right)$} & $\left(\mathrm{g} \mathrm{kg}^{-1}\right)$ \\
\hline 5.9 & 15 & 12 & 27 & 13 & 9.6 & 0.3 & 32.9 & 82.9 & 60 & 176 \\
\hline
\end{tabular}



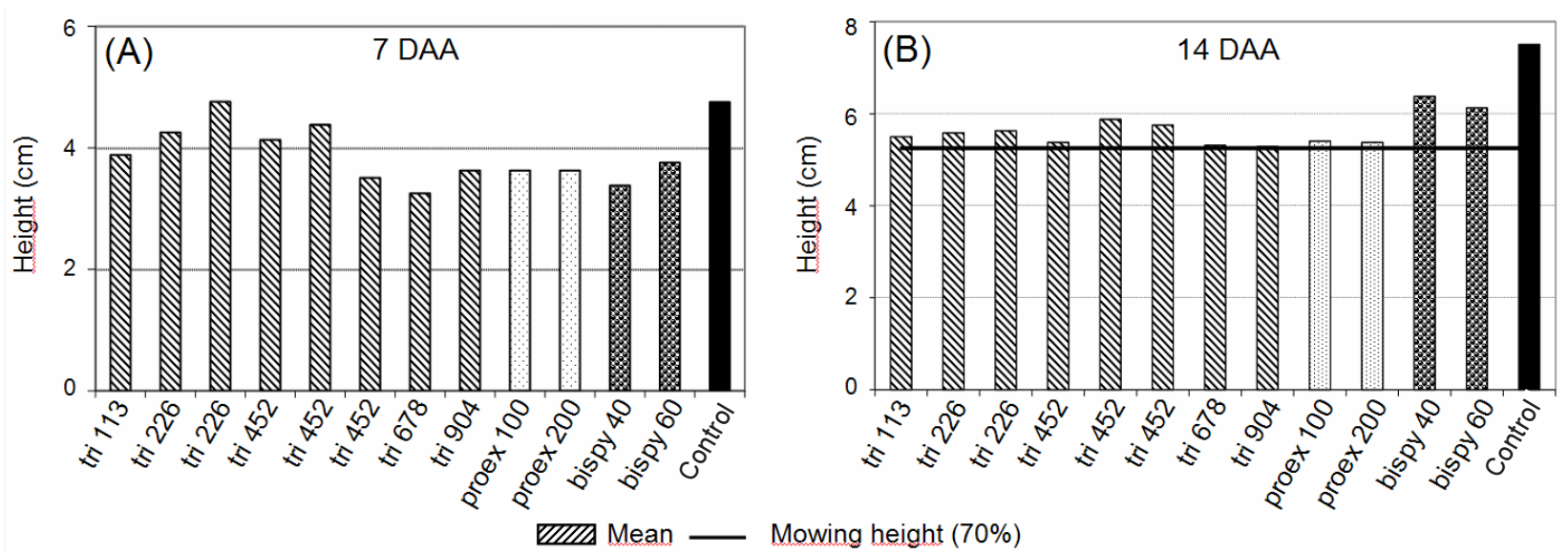

Figure 1 - Graph of the average height of 'Meyer' zoysiagrass obtained at 7 (A) and 14 (B) days after the first application (DAA) of growth regulators.

The first application was made at the end of November, with partly cloudy skies, air temperature of $26.3{ }^{\circ} \mathrm{C}$, relative air humidity of $69 \%$ and wind gusting to $9.0 \mathrm{~km} \mathrm{~h}^{-1}, \mathrm{SE}$ direction. During application, the plots were protected laterally with screens of plastic canvas, in order to avoid spraying the regulators onto adjacent parcels. Altogether, the experiment was conducted from November to early May - a period favorable to plant and reproductive growth of 'Meyer' zoysiagrass in the area where the study was undertaken.

When the treatments ranged between 5.0 and $6.0 \mathrm{~cm}$ in height, the turf was mowed to approximately $3.0 \mathrm{~cm}$, and then the second dose of growth regulators was applied. The clippings were collected, placed in paper bags and maintained in a forced air circulation incubator at $65^{\circ} \mathrm{C}$ to achieve constant dry mass for dry matter determination.

Ratings of injury and growth reduction were made weekly until mid-April, at which time both the control and the treated areas showed no change in height over time because of the decrease in temperature and length of daylight, phenomena which are typical of fall in the region where the study was conducted.

The injuries caused by the treatments were visually rated according to a scale of $0 \%$ - $100 \%$, where 0 represents no injury and 100 represents plant death. The reduction in growth was assessed by direct measurement of plant height with a ruler graduated in centimeters. Height and number of inflorescences were measured by sampling an area of $0.25 \mathrm{~m}^{2}$ in the center of the plots, before the turf was mowed for reapplication, and also at the end of the trial period, in order to obtain the total dry mass of clippings (TDMC), which is represented by the sum of the dry mass of both clippings. The results were submitted to analysis of variance by the F-test; in case of significance, the means were compared by Tukey's test at $5 \%$ probability.

\section{RESULTS AND DISCUSSION}

Figure 1A shows the average heights of 'Meyer' zoysiagrass evaluated at seven days after application of the regulators (DAA), when it was observed that none of the treatments had reached a height of $5.0 \mathrm{~cm}$, and at $14 \mathrm{DAA}$, when height ranged between 5.0 and $6.0 \mathrm{~cm}$ in all the treatments where regulators had been applied (Figure 1B), thus allowing for mowing and application of the second dose.

The resumption of growth in height is a common event for most tropical grasses. This is because non-structural carbohydrates like glucose, fructose, sucrose and starch can be stored and used as backup energy for stress tolerance, dormancy recovery and regrowth after shoot removal (Waltz Jr. \& Whitwell, 2005). In this study, the rapid resumption of growth in height was due, especially, to the redistribution of nonstructural carbohydrates that were stored in the rhizomes and stolons 
of 'Meyer' zoysiagrass immediately after the leaves were mowed for application of growth regulators (McCarty et al ., 2004; Waltz Jr. \& Whitwel1, 2005; Ervin \& Zhang, 2007; McCullough et al., 2007). It should be noted that single doses of Type II growth regulators promote not only the obvious reduction in the concentration of gibberellins, but also an increase in the total chlorophyll b in the leaves up to two weeks after application. Thus, the leaves are more efficient at capturing light energy, and, hence higher $\mathrm{CO}_{2}$ fixation and higher production of non-structural carbohydrates occur (Ervin \& Koski, 2001; Ervin \& Zhang, 2007).

In Table 3, it can be seen that none of the treatments involving trinexapac-ethyl and prohexadione-calcium caused injuries on leaves of 'Meyer' zoysiagrass at 7,21 and 28 days after the second application (DAAB).

The second application of bispyribacsodium at 40 and $60 \mathrm{~g}$ a.i. ha ${ }^{-1}$ resulted in injuries of 56 and $59 \%$, respectively, at 7 DAAB. These injuries were characterized by yellowing of leaves - a characteristic symptom of ALS inhibiting herbicides. However, the levels of injury regressed considerably in the evaluation performed at $21 \mathrm{DAAB}$, with full recovery of turf coloring at $28 \mathrm{DAAB}$ (Table 3 ).

The use of type II growth regulators generally provides visual symptoms of phytotoxicity when applied in grams (Heckman, et al. 2001; McCullough et al. 2005; McCarty et al. 2011), a similar effect caused by the use of ALS inhibiting herbicides (McDonald et al. 2006).

Some research has shown that the deleterious effects of injury caused by trinexapac-ethyl and bispyribac-sodium may be rapidly reversed with the use of an additional source of iron or nitrogen, which play an important role in the formation of chlorophyll, which gives back the grass leaves their green coloring (Johnson, 1997, Zhang et al. 2002; Ervin et al. 2004; McDonald et al. 2006). In this study, the rapid recovery of 'Meyer' zoysiagrass is probably associated with the high amount of iron available in the experimental area, given that the chemical analysis revealed a content of $176 \mathrm{~g} \mathrm{~kg}^{-1}$ of iron oxide (Fe2O3).
Plant growth of 'Meyer' zoysiagrass was significantly modified by growth regulators, and the effects on plant height extended up to 110 days after the second application period. The assessments were discontinued at 110 days after second application because the plant development stays stabilized on control treatment as a result of weather and season conditions (temperature and luminosity decreased). It should be noted that the entire period between the first application of growth regulators and the final evaluation comprised 124 days.

Table 4 shows that trinexapac-ethyl was the main regulator of the development of 'Meyer' zoysiagrass, because all the doses applied were able to reduce plant height, regardless of when the rating was made. Height growth was reduced by more than $53 \%$, compared to the growth observed in the control, even when the lowest sequential dose was used: $113+113 \mathrm{~g}$ a.i. ha ${ }^{-1}$.

The trinexapac-ethyl doses in sequential applications of $452+226,452+452,678+379$ and $904+452 \mathrm{~g}$ i.a ha ${ }^{-1}$ were the most effective

Table 3 - Means of the signs of injury observed in 'Meyer' zoysiagrass after the second application of growth regulators

\begin{tabular}{|c|c|c|c|}
\hline \multirow{2}{*}{ Treatment } & \multicolumn{3}{|c|}{ Injury $(\%)-\mathrm{DAAB}^{\frac{1 /}{}}$} \\
\hline & 7 & $21^{\underline{2 !}}$ & 28 \\
\hline trinexapac-ethyl $113+113$ & $0 \mathrm{a}$ & $1.0 \mathrm{a}(0)$ & 0 \\
\hline trinexapac-ethyl $226+113$ & $0 \mathrm{a}$ & $1.0 \mathrm{a}(0)$ & 0 \\
\hline trinexapac-ethyl $226+226$ & $0 \mathrm{a}$ & $1.0 \mathrm{a}(0)$ & 0 \\
\hline trinexapac-ethyl $452+113$ & $0 \mathrm{a}$ & $1.0 \mathrm{a}(0)$ & 0 \\
\hline trinexapac-ethyl $452+226$ & $0 \mathrm{a}$ & $1.0 \mathrm{a}(0)$ & 0 \\
\hline trinexapac-ethyl $452+452$ & $0 \mathrm{a}$ & $1.0 \mathrm{a}(0)$ & 0 \\
\hline trinexapac-ethyl $678+339$ & $0 \mathrm{a}$ & $1.0 \mathrm{a}(0)$ & 0 \\
\hline trinexapac-ethyl 904+452 & $0 \mathrm{a}$ & $1.0 \mathrm{a}(0)$ & 0 \\
\hline prohexadione-calcium $100+100$ & $0 \mathrm{a}$ & $1.0 \mathrm{a}(0)$ & 0 \\
\hline prohexadione-calcium $200+200$ & $0 \mathrm{a}$ & $1.0 \mathrm{a}(0)$ & 0 \\
\hline bispyribac-sodium $40+40$ & $56 \mathrm{~b}$ & $1.3 \mathrm{a}(1)$ & 0 \\
\hline bispyribac-sodium $60+60$ & $59 \mathrm{~b}$ & $3.8 \mathrm{a}(4)$ & 0 \\
\hline Control & $0 \mathrm{a}$ & $1.0 \mathrm{a}(0)$ & 0 \\
\hline F Treatment & $803.07 *$ & $1.66^{\mathrm{NS}}$ & - \\
\hline F Block & $0.55^{\mathrm{NS}}$ & $1.20^{\mathrm{NS}}$ & - \\
\hline $\mathrm{DMS}$ & 3.82 & 1.50 & - \\
\hline $\mathrm{CV}(\%)$ & 17.23 & 47.93 & - \\
\hline
\end{tabular}

${ }^{1 /} \mathrm{DAAB}=$ days after the second application. ${ }^{2 /}$ Means transformed to $\sqrt{ } \mathrm{Y}+1.0$. Original means between brackets. NS - non-significant. * significant at $5 \%$ probability. Means followed by the same letter in the column do not differ by the Tukey's test at $5 \%$ probability. 
Table 4 - Mean height values of 'Meyer' zoysiagrass obtained after the second application of the growth regulators

\begin{tabular}{|c|c|c|c|c|c|c|c|}
\hline \multirow{2}{*}{ Treatment } & \multicolumn{6}{|c|}{ Grass height $(\mathrm{cm})-\mathrm{DAAB}^{1 /}$} & \multirow{2}{*}{$\begin{array}{c}\text { Reduction } \\
(\%)^{\frac{2}{}}\end{array}$} \\
\hline & 7 & 14 & 21 & 28 & 63 & 110 & \\
\hline trinexapac $113+113$ & $3.0 \mathrm{~A}$ & $3.0 \mathrm{a}$ & $3.3 \mathrm{a}$ & $3.4 \mathrm{~A}$ & $4.0 \mathrm{ab}$ & $4.8 \mathrm{ab}$ & 64.7 \\
\hline trinexapac $226+113$ & $5.6 \mathrm{~A}$ & $5.9 \mathrm{ab}$ & $6.0 \mathrm{ab}$ & $6.0 \mathrm{Abc}$ & $6.4 \mathrm{abc}$ & $6.3 \mathrm{ab}$ & 53.6 \\
\hline trinexapac $226+226$ & $3.0 \mathrm{~A}$ & $3.1 \mathrm{a}$ & $3.2 \mathrm{a}$ & $3.3 \mathrm{~A}$ & $3.8 \mathrm{ab}$ & $4.3 \mathrm{a}$ & 73.6 \\
\hline trinexapac $452+113$ & $3.1 \mathrm{~A}$ & $3.3 \mathrm{a}$ & $3.2 \mathrm{a}$ & $3.3 \mathrm{~A}$ & $4.2 \mathrm{ab}$ & $4.3 \mathrm{a}$ & 68.4 \\
\hline trinexapac $452+226$ & $3.0 \mathrm{~A}$ & $3.0 \mathrm{a}$ & $3.2 \mathrm{a}$ & $3.3 \mathrm{~A}$ & $3.3 \mathrm{a}$ & $3.6 \mathrm{a}$ & 73.5 \\
\hline trinexap $452+452$ & $3.0 \mathrm{~A}$ & $3.0 \mathrm{a}$ & $3.6 \mathrm{a}$ & $3.6 \mathrm{~A}$ & $3.7 \mathrm{ab}$ & $3.6 \mathrm{a}$ & 73.5 \\
\hline trinexapac $678+339$ & $5.0 \mathrm{~A}$ & $5.1 \mathrm{ab}$ & $5.2 \mathrm{ab}$ & $5.3 \mathrm{Abc}$ & $5.5 \mathrm{abc}$ & $5.3 \mathrm{ab}$ & 61.0 \\
\hline trinexapac $904+452$ & $4.2 \mathrm{Ab}$ & $4.5 \mathrm{ab}$ & $4.5 \mathrm{ab}$ & $4.5 \mathrm{Ab}$ & $4.5 \mathrm{ab}$ & $4.6 \mathrm{ab}$ & 66.2 \\
\hline prohexadione $100+100$ & $6.4 \mathrm{~B}$ & $7.5 \mathrm{bc}$ & $7.9 \mathrm{~b}$ & $8.0 \mathrm{C}$ & $9.8 \mathrm{~cd}$ & $10.4 \mathrm{bc}$ & 23.5 \\
\hline prohexadione $200+200$ & $3.2 \mathrm{~A}$ & $3.5 \mathrm{a}$ & $3.6 \mathrm{a}$ & $4.0 \mathrm{Ab}$ & $5.9 \mathrm{abc}$ & $7.4 \mathrm{~b}$ & 45.6 \\
\hline bispyribac $40+40$ & $3.3 \mathrm{~A}$ & $5.3 \mathrm{ab}$ & $6.2 \mathrm{ab}$ & $6.8 \mathrm{BC}$ & $7.6 \mathrm{abc}$ & $7.9 \mathrm{~b}$ & 41.2 \\
\hline bispyribac $60+60$ & $3.0 \mathrm{a}$ & $5.2 \mathrm{ab}$ & $6.1 \mathrm{ab}$ & $6.2 \mathrm{Abc}$ & $7.4 \mathrm{bc}$ & $7.5 \mathrm{~b}$ & 44.8 \\
\hline Control & $10.8 \mathrm{c}$ & $11.1 \mathrm{c}$ & $12.0 \mathrm{c}$ & $13.6 \mathrm{D}$ & $13.8 \mathrm{~d}$ & $13.6 \mathrm{c}$ & - \\
\hline F Treatment & $12.14 *$ & $9.04 *$ & $21.96^{*}$ & $21.60 *$ & $11.70^{*}$ & $18.38 *$ & - \\
\hline F Block & $3.96^{*}$ & $6.30 *$ & $11.52 *$ & $11.71 *$ & $13.87 *$ & $9.93 *$ & - \\
\hline DMS & 3.22 & 3.89 & 3.50 & 3.11 & 4.32 & 3.08 & - \\
\hline $\mathrm{CV}(\%)$ & 29.50 & 31.83 & 26.30 & 22.49 & 27.82 & 21.49 & - \\
\hline
\end{tabular}

${ }^{1 /} \mathrm{DAAB}=$ days after the second application. ${ }^{2 /}$ reduction calculated as compared to the control. NS - non-significant. $*$ significant at $5 \%$ probability. Means followed by the same letter in the column do not differ by the Tukey's test at $5 \%$ probability.

in retaining the vertical growth of 'Meyer' zoysiagrass, since an increase of only $0.3 \mathrm{~cm}$ was observed between the assessments at 7 and 110 days after the second application. It should be noted that the increases found in other sequential applications of trinexapacethyl ranged between 0.7 and $1.8 \mathrm{~cm}$ (Table 4).

The prohexadione-calcium used in the sequential application of $200+200$ g a.i. ha ${ }^{-1}$ was effective in reducing the vertical growth of 'Meyer' zoysiagrass at 63 DAAB, while bispyribac-sodium at the doses of $40+40$ and $60+60 \mathrm{~g}$ a.i. ha ${ }^{-1}$ reduced the height of 'Meyer' zoysiagrass only until 28 DAAB (Table 4). Although these three treatments have shown statistically lower height than that of the control throughout the trial period, it was observed that the height of 'Meyer' zoysiagrass obtained at 110 DAAB was almost twice as much as the one observed at $7 \mathrm{DAAB}$, representing a $43 \%$ reduction compared with the height of the control.

In contrast, calcium-prohexadione in sequential applications of $40+40 \mathrm{~g}$ a.i. ha ${ }^{-1}$ was virtually ineffective for retaining the vertical growth of 'Meyer' zoysiagrass, providing only a $23.5 \%$ reduction in the height of the turf, and thus statistically similar to the height of the control in most of the assessments made (Table 4). The reduction in top growth observed in 'Meyer' zoysiagrass corroborates the data obtained by Ervin et al. (2002), Beam (2004) and Costa et al. (2009). Additionally, Ervin et al. (2002) commented that the sequential application of trinexapac-ethyl is a management practice of $Z$. japonica, especially in areas with low light condition.

Table 5 shows that only the prohexadionecalcium applied in the sequential dose of $100+100$ did not reduce inflorescence height, which was statistically similar to the control. All other treatments showed significant reductions in the height of inflorescences, with special emphasis on the highest doses of trinexapac-ethyl $(452+452,678+339$ and $904+452$ g a.i. ha ${ }^{-1}$ ), which showed statistically lower heights than the one obtained in the control.

Johnson (1994) suggests that for a growth regulator to be commercially acceptable, it must reduce the emission of the flower 
Table 5 - Mean values of height and number of inflorescences and total dry mass of clippings (TDMC) produced by 'Meyer' zoysiagrass at 110 days after the second application of growth regulators

\begin{tabular}{|c|c|c|c|c|c|}
\hline \multirow{2}{*}{ Treatament } & \multicolumn{3}{|c|}{ Inflorescence $^{\underline{1}}$} & \multicolumn{2}{|c|}{ TDMC } \\
\hline & Height $(\mathrm{cm})$ & Number $\left(\mathrm{m}^{-2}\right)$ & $\%^{\underline{2} /}$ & $\left(\mathrm{g} \mathrm{m}^{2}\right)$ & $\%{ }^{2 /}$ \\
\hline trinexapac $113+113$ & $2.8 \quad(8.6) \mathrm{ab}$ & $3.9 \quad(17.0) \mathrm{a}$ & 90.1 & $115.8 \mathrm{a}$ & 86.5 \\
\hline trinexapac $226+113$ & $1.9 \quad(3.3) \mathrm{ab}$ & $2.8 \quad(11.3) \mathrm{a}$ & 93.4 & $128.4 \mathrm{a}$ & 85.0 \\
\hline trinexapac $226+226$ & $2.2(3.8) \mathrm{ab}$ & $4.7 \quad(26.2) \mathrm{a}$ & 84.7 & $125.9 \mathrm{a}$ & 85.3 \\
\hline trinexapac $452+113$ & $2.2 \quad(3.9) \mathrm{ab}$ & $5.9 \quad(40.0) \mathrm{a}$ & 76.7 & $128.0 \mathrm{a}$ & 85.1 \\
\hline trinexapac $452+226$ & $1.9 \quad(2.5) \mathrm{ab}$ & $2.5 \quad(6.3) \mathrm{a}$ & 96.3 & $134.9 \mathrm{a}$ & 84.2 \\
\hline trinexapac $452+452$ & $1.7 \quad(2.4) \mathrm{a}$ & $2.7 \quad(7.5) \mathrm{a}$ & 95.6 & $131.6 \mathrm{a}$ & 84.6 \\
\hline trinexapac $678+339$ & $1.7 \quad(2.4) \mathrm{a}$ & $3.1(11.3) \mathrm{a}$ & 93.4 & $129.2 \mathrm{a}$ & 84.9 \\
\hline trinexapac $904+452$ & $1.6 \quad(2.2) \mathrm{a}$ & $3.8 \quad(21.4) \mathrm{a}$ & 87.5 & $99.6 \mathrm{a}$ & 88.4 \\
\hline prohexadione $100+100$ & $3.3(10.1) b$ & $8.3(67.8) \mathrm{ab}$ & 60.1 & $151.9 \mathrm{a}$ & 82.3 \\
\hline prohexadione $200+200$ & $2.2 \quad(4.6) \mathrm{ab}$ & $5.4 \quad(43.0) \mathrm{a}$ & 74.9 & $136.8 \mathrm{a}$ & 84.0 \\
\hline bispyribac $40+40$ & $2.6 \quad(5.9) \mathrm{ab}$ & $8.1 \quad(66.1) \mathrm{ab}$ & 61.4 & $165.9 \mathrm{a}$ & 80.6 \\
\hline bispyribac $60+60$ & $2.4 \quad(5.1) \mathrm{ab}$ & $6.7 \quad(46.0) \mathrm{a}$ & 73.2 & $153.2 \mathrm{a}$ & 82.1 \\
\hline Control & $3.3(10.2) b$ & $13.1(171.5) \mathrm{b}$ & - & $856.2 \mathrm{~b}$ & - \\
\hline F Treatment & $2.13 *$ & \multicolumn{2}{|c|}{$6.67^{*}$} & \multicolumn{2}{|c|}{$29.15^{*}$} \\
\hline F Block & $0.85^{\mathrm{NS}}$ & \multicolumn{2}{|c|}{$0.30^{\mathrm{NS}}$} & \multicolumn{2}{|c|}{$18.09^{*}$} \\
\hline DMS & 1.51 & \multicolumn{2}{|l|}{5.85} & \multicolumn{2}{|c|}{186.14} \\
\hline $\mathrm{CV}(\%)$ & 27.80 & \multicolumn{2}{|l|}{43.63} & \multicolumn{2}{|c|}{37.77} \\
\hline
\end{tabular}

1/ Means transformed to $\sqrt{ } \mathrm{Y}+1.0$. Original means between brackets. ${ }^{2} /$ Reduction calculated as compared to the control. NS - nonsignificant. * significant at $5 \%$ probability. Means followed by the same letter in the column do not differ by the Tukey's test at $5 \%$ probability.

stem by more than $70 \%$. The total number of inflorescences was also significantly reduced for most doses of plant growth regulator evaluated, with a reduction rate above $74 \%$. Only prohexadione-calcium at $100+100$ g a.i. ha $\mathrm{a}^{-1}$ and sodium-bispyribac at $40+40 \mathrm{~g}$ a.i. $\mathrm{ha}^{-1}$ were not efficient because the number of inflorescences was similar to the control and reduction of emission of the flower stems around $60 \%$. Several studies point out that the application of trinexapacethyl may retard and/or reduce the emission of inflorescences and prolong the visual appearance aesthetics of the turf without the need for a new mowing (Johnson, 1990; Fry, 1991; Costa et al., 2009; Mittlesteadt et al., 2009).

The literature cites that type II growth inhibitors used in turfs, such as trinexapacethyl and prohexadione-calcium are ineffective in suppressing the emission of flower stems because they interfere in the biosynthesis of gibberellins and, thus, reduce cell elongation (Johnson, 1990; Fry, 1991; Mittlesteadt, 2009). However, the large reductions in the emission of flower stems observed in this study probably result from the physiological changes caused by sequential applications of growth regulators (Ervin \& Zhang, 2007).

The production of total dry mass (TDMC) of clippings of 'Meyer' zoysiagrass was markedly reduced by growth regulators studied, since all the sequential applications produced significantly lower amounts of clippings than the control. The lowest amount of clippings was observed in plants where trinexapac-ethyl is used in a sequential dose of 904+452 g a.i. ha ${ }^{-1}$, representing a yield of $99.9 \mathrm{~g} \mathrm{~m}^{-2}$ over a period of almost 124 days. It should be noted that reductions in TDMC were above $80 \%$, regardless of the regulator used, which can represent the same rate of reduction in the need for mowing (Table 5).

Beam (2004) observed a direct correlation between increasing dose sequential prohexadione-calcium $(140+140,270+270$, $410+410,540+540,670+670$ g a.i. ha $\left.{ }^{-1}\right)$ and percentage reduction in dry matter clippings 
produced by the 'Meyer' zoysiagrass. This author also says that mass reductions were equivalent to sequential applications of trinexapac-ethyl commercially recommended for each species.

Ervin \& Ok (2001) and Ervin et al. (2002) reported reductions of 35 to $75 \%$ in the amount of grass clippings produced by 'Meyer' zoysiagrass when trinexapac-ethyl was applied. Using sequential applications of trinexapacethyl at 55.6+55.6 and $113+113 \mathrm{~g}$ a.i. $\mathrm{ha}^{-1}$, Costa et al. (2009) found reductions from 49.2 to $55.6 \%$, respectively, in the production of dry mass of 'Meyer' zoysiagrass.

Fagerness \& Yelverton (2000) explained that a single application of trinexapac-ethyl at $107 \mathrm{~g}$ a.i. $\mathrm{ha}^{-1}$ caused a $40 \%$ reduction in the production of tissues in Tifway bermudagrass. However, the researchers reported that the triple sequential application of trinexapacethyl and $71 \mathrm{~g}$ a.i. ha $^{-1}$ presents a clear advantage in reducing the tissues produced, as compared to the double sequential application of the $107 \mathrm{~g}$ a.i. ha $^{-1}$ dose.

It can be concluded that sequential applications of trinexapac-ethyl, prohexadionecalcium and sodium-bispyribac proved promising as regards the retardation of vegetative growth and inflorescence emission, thus contributing in the management of turfs, because it reduces the need for mowing for a period up to 110 days after the sequential application of the growth regulator, and avoids the deleterious effect on the visual appearance aesthetics of 'Meyer' zoysiagrass.

\section{LITERATURA CITADA}

ARRUDA, R. L. B.; HENRIQUES, E. Gramados. São Paulo: Europa, 1995. 63 p.

BEAM, J. B. Prohexadione calcium for turfgrass management and poa annua control and molecular assessment of the acetolactate synthase gene in poa annua. 2004. 85 f. Thesis (Doctor Phylosophy in Plant Pathology, Physiology and Weed Science) - Faculty of the Virginia Polytechnical Institute and State University, Blacksburg, Virginia Blacksburg, Virginia, 2004.

COSTA, N. V. et al. Características morfológicas de gramas em resposta a aplicação de trinexapac-ethyl.

Planta Daninha, v. 27, n. 1, p. 113-122, 2009.
EMPRESA BRASILEIRA DE PESQUISA AGROPECUÁRIA - EMBRAPA. Sistema brasileiro de classificação de solos. Brasília: 2006. 306 p.

ERVIN, E. H.; KOSKI, A. J. Trinexapac-ethyl increases Kentucky bluegrass leaf cell density and chlorophyll concentration. HortScience, v. 36, n. 4, p. 787-789, 2001.

ERVIN, E. H.; OK, C. H. Influence of plant growth regulators on suppression and quality of 'Meyer' Zoysiagrass. J. Environ. Hortic., v. 19, n. 2, p. 57-60, 2001.

ERVIN, E. H. et al. Trinexapac-ethyl restricts shoot growth and prolongs stand density of 'Meyer' zoysiagrass fairway under shade. Hortscience, v. 37, n. 3, p. 502-505. 2002.

ERVIN, E. H. et al. Trinexapac-ethyl, propiconazole, iron and biostimulant effects on shaded creeping bentgrass.

HortTechnology, v. 14, n. 4, p. 500-506, 2004.

ERVIN, E. H.; ZHANG, W. Influence of sequential trinexapac-ethyl applications on cytokinin content in creeping bentgrass, kentucky bluegrass, and hybrid bermudagrass.

Crop Sci., v. 47, n. 5, p. 2145-2151, 2007

FAGERNESS, M. J.; YELVERTON, F. H. Tissue production and quality of 'tifway' bermudagrass as affected by seasonal application patterns of trinexapac-ethyl. Crop Sci., v. 40, n. 2 , p. $493-497,2000$.

FREITAS, F. C. L. et al. Efeitos do trinexapac-ethyl sobre o crescimento e florescimento da grama-batatais.

Planta Daninha, v. 20, n. 3, p. 477-486, 2002.

FRY, J. D. Centipedegrass response to plant growth regulators. HortScience, v. 26, n. 1, p. 40-42, 1991.

HECKMAN, N. L.; G.L. HORST, G. L.; GAUSSOIN, R. E. Influence of trinexapac-ethyl on specific leaf weight and chlorophyll content of Poa pratensis. Inter. Turfgrass Soc. Res. J., v. 9, n. 4, p. 287-290, 2001

HECKMAN, N. L. et al. Growth regulator effects on cellular characteristics of two turfgrass species. Inter. Turfgrass Soc. Res. J.I, v. 10, n. 8, p. 857-861, 2005.

JOHNSON, B. J. Influence of frequency and dates of plant growth regulator applications to centipedegrass on seedhead formation and turf quality. HortScience, v. 15, n. 3, p. 412-416, 1990.

JOHNSON, B. J. Influence of plant growth regulators and mowing on two bermudagrassess. Agron. J., v. 86, n. 5, p. 805-810, 1994. 
JOHNSON, B. J. Growth of Tifway bermudagrass following application of nitrogen and iron with trinexapac-ethyl.

HortScience, v. 32, n. 2, p. 241-242. 1997.

KISSMANN, G. K.; GROTH, D. Plantas nocivas e infestantes. São Paulo: BASF Brasileira, 1992. 728 p.

LICKFELDT, D. W. et al. Implications of Repeated Trinexapac-Ethyl Applications on Kentucky Bluegrass. Agron. J., v. 93, n. 5, p. 1164-1168, 2001.

LORENZI, H.; SOUZA, H. M. Plantas ornamentais do Brasil: arbustivas, herbáceas e trepadeiras. 3.ed. Nova Odessa: Instituto Plantarum, 2001. 1088 p.

McCARTY, L. B. et al. St. Augustinegrass response to plant growth retardants. Crop Sci., v. 44, n. 4, p. 1323-1329, 2004

McCARTY, L. B. et al. 'Ttifeagle' bermudagrass response to plant growth regulators and mowing height. Agron. J., v. 103, n. 4, p. 988-994, 2011.

McCULLOUGH, P. E. et al. Response of 'TifEagle' bermudagrass to seven plant growth regulators. HortScience, v. 39, n. 7, p. 1759-1762, 2004.

McCULLOUGH, P. E. et al. Bermudagrass putting green growth, color, and nutrient partitioning influenced by nitrogen and trinexapac-ethyl. Crop Sci., v. 46, n. 4, p. 1515-1525, 2005.
McCULLOUGH, P. E. et al. Growth and nutrient partitioning of 'TifEagle' bermudagrass as influenced by nitrogen and trinexapac-ethyl. HortScience, v. 41, n. 2, p. 453-458, 2006.

McCULLOUGH, P. E. et al. Trinexapac-ethyl application regimens influence growth, quality, and performance of bermuda grass and creeping bentgrass putting greens. Crop Sci., v. 47, n. 5, p. 2138-2144, 2007.

McDONALD, S. J.; DERNOEDEN, P. H.; KAMINSKI, J. E. Creeping bentgrass tolerance and annual bluegrass control with bispyribac-sodium tank-mixed with iron and nitrogen. Appl. Turfgrass Sci., doi: 10.1094/ATS-2006-0811-01-RS, 2006. Disponível em: <http://www.turf.uconn.edu/pdf/ research/kaminski/ats_0811_01_rs.pdf $>$. Acesso em: 30 maio 2012 .

MITTLESTEADT, T. L. Low-impact conversion of coolseason turf to 'patriot' bermudagrass. Inter. Turfgrass Soc. Res. J., v. 11, n. 9, p. 1205-1212, 2009.

WALTZ JR., F. C.; WHITWELL, T. Trinexapac-ethyl effects on total nonstructural carbohydrates of field grown hybrid bermudagrass. Inter. Turfgrass Soc. Res. J., v. 10, n. 8, p. 899-903, 2005.

ZHANG, X. et al. Creeping bentgrass physiological responses to natural plant growth regulators and iron under two regimes. HortScience, v. 37, n. 6, p. 898-902, 2002. 